\section{Grow your own grass}

\section{David Spurgeon examines a programme for improving agriculture in Antigua}

A COMMON problem of Third

World countries is an unfavourable balance of payments caused by a shortage of indigenous industry and a consequent reliance on imports from developed countries. This is particularly true of many of the small Caribbean islands, whose industries (when there are any) are often foreign-owned and more concerned with exports to an sufficiency of domestic supplies.

The tiny, 108-square-mile island of Antigua is a case in point. Since a sugar cane company left the island some years ago, there has been little more than tourism and rum-making in the way of industry there-both the molasses for the rum and most of the beef for the tourists being imported. Where sugar cane once flourished, acacia bushes now grow like weeds. Yet much of this land, rocky and hilly though it often is, could be used for grazing cattle, and if only the grass and legumes were more abundant and of better nutritional quality, the island might become self-sufficient in beef and dairy production-and even export to other Leeward Islands.

This in fact is the aim of a research programme now being conducted in Antigua, Trinidad and Belize by the University of the West Indies (UWI) with the aid of a grant from Canada's International Development Research Centre. The programme began in 1972 and is now in its second phase. It has an Australian consultant, Dr Robert Burt of the Commonwealth Scientific and Industrial Research Organisation (CSIRO), and the experiment is being watched with interest not only by the agricultural ministries of the three countries concerned but those of the neighbouring territories of Guyana, Barbados, Jamaica, Guadeloupe, Martinique and Cuba as well.

Two meetings have been held of representatives of agricultural ministries of the region-including representatives from other islands-to look at results where tests are being carried out with material from the project. The most recent was held in Antigua from 29 November -1 December. The Antigua component of the project is directed by a New Zealander, John Keoghan, who has taught at McGill's Macdonald College and done research at the University of Guelph. $\mathrm{He}$ is assisted by Belal Ahmed, a microbiologist from Bangladesh, employed by the department of soil science at the UWI in St Augustine, Trinidad, Clive Devers affluent overseas market than with seli- from Guyana, a graduate assistant, and Perry Phillip, a technical assistant.

Interviewed in Antigua recently, Keoghan spoke of the implications of the project and the relevance of the Australian experience. All of the grasses growing in the Caribbean and thought of as 'native' to the area, actually come from Africa, he said, while the legumes come from the area itself. The soil in both regions of the world is heavy clay, and if work done in the Caribbean were applied to Africa it could revolutionise agriculture there.

"This is not far-fetched," he said. "This is what the Australians did. They went to South and Central America and found plants for Northern Australia, which is tropical. The legumes that dominate livestock agriculture in Northern Australia were originally growing as weeds in South and Central America."

There is a difference, of course. The Australians selected plants from acid soils for acid soil areas of their own. Keoghan and his colleagues collect plants from alkaline soils to match those of the dry areas where livestock graze both in the Caribbean and in Africa. So far, they have collected a total of about 1,000 grasses and legumes for planting in experimental plots, including 70 different varieties of grasses. They are carrying out a complete classification and description of the plants, and then are making an agronomic assessment under different growing conditions, for example with different types of soils, and in mixtures of grasses and legumes.

\section{Two plots}

Two experimental plots are being used, one of them near the old sugar mill, where the small amount of laboratory equipment required is also located, along with nursery facilities.
As basic as all this might seem to be, it has never been done before, according to Keoghan. Although there were earlier sporadic attempts at collection, classification and description, adequate records were not kept of them and plant collections disappeared.

Pasture legumes are important not only for their high protein content, but for their ability to fix nitrogen and thus act as a fertiliser for the grasses. This latter capability is all the more important to developing countries at a time of high fertiliser prices. Samples of legumes have been collected from all over the island as well as from other countries in the region.

Samples are selected from a sixsquare-metre area of each plot, the leaves are clipped and the yield is bagged, dried in ovens at the sugar factory and the weight measured. Nitrogen and protein content are determined, and records are kept of these measurements. Seeds are collected and examined, and then sent to CSIRO in Australia, which is the main centre of tropical legume research.

After two years of trials in these plots, the research group in Antigua is now beginning to mix the best grasses and legumes in field trials on heavy soils, and then will test them under actual grazing conditions. The types of soil used for such trials is representative of those found in much of the grazing area in Antigua. This is being done with 15 different grasses and 12 legumes, both singly and in mixed stands to determine the effects of the legumes and grasses on each other. The animal grazing tests will show whether, for example, the animals actually will eat the plants, and how well the plants grow again after grazing.

Basically, the idea is to narrow down the choice of grasses and legumes to determine the best varieties available for local conditions, and the most progether, and to work out the most suitable management practices. It is the first time such a project has been undertaken in the Caribbean. ductive combinations when grown to-

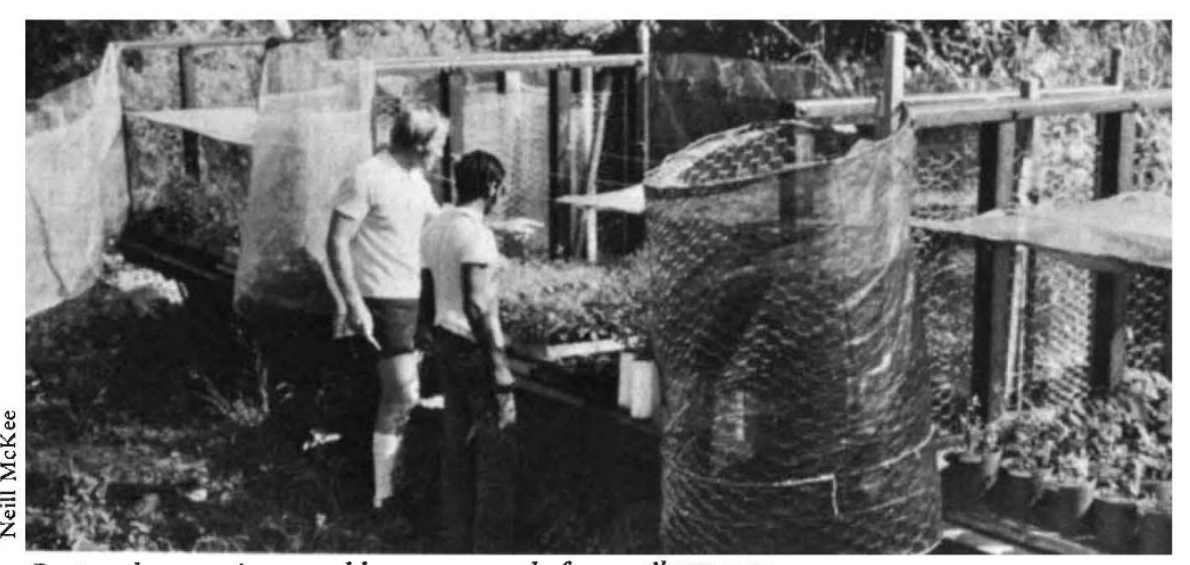

Pasture legumes in moveable nursery made from railway cars 